\title{
Atul Kohli, Imperialism and the Developing World: How Britain and the United States Shaped the Global Periphery (New York, NY: Oxford University Press, 2020). 539 pp. Hardcover \$34.95.
}

In his classic treatise Asia and Western Dominance, diplomat and historian K.M. Panikkar characterizes European imperialism as a crusade, emerging out of an "attack on the financial prosperity of the Muslim nations" (480). In Panikkar's view, the development of capital or technology alone cannot explain the 400-year subjugation of Asia. Rather, he spotlights the militarization of Western Europeans and the desire of Asian merchants to supplant the aristocracy of Asia's ports and plains. With Imperialism and the Developing World: How Britain and the United States Shaped the Global Periphery, Atul Kohli, the David K.E. Bruce Professor of International Affairs at Princeton, calls our attention once more to the intentionality of British and American imperialism in the last two centuries. In his extensive review of imperialism in the nineteenth and twentieth centuries, Kohli contends that Britain and the US's infringement on the sovereignty of communities across Asia, Africa, and Latin America prevented the modernization of agrarian societies into dynamic industrial economies. In effect, Britain andthe US created the "developing world" (1-3, 7-8).

Kohli's book is organized into two equal-length parts of three chapters, with the first focusing on the history of the British empire in the nineteenth century, and the second on American imperialism in the twentieth century. In his introduction, Kohli forthrightly states his primary argument, that sustained economic growth is intimately tied to the level of autonomy available to a sufficiently coherent sovereign state: "in a world of states, national sovereignty is an economic asset" (3). Imperial subjugation impedes economic development by robbing political communities of sovereignty over the organization of productive activity and the distribution of national income and wealth. Here, Kohli distinguishes his theory of imperialism from both Lenin's "highest stage of capitalism" and Schumpeter's "atavistic" form of capitalism (7). For Kohli, British and American imperialism served frameworks of "national economic prosperity" emphasizing the place of the imperial nation on the world stage (9).

Part 1, examining British imperialism in the nineteenth century, identifies the emergence of modern imperialism in the shift from commercial monopolies to industrial production and both formal and informal empire. Chapter 1, on the East India Company's conquest of South Asia, largely follows the scholarship of early Indian economic nationalists like Dadabhai Naoroji and Romesh Dutt in tying “deindustrialization" to Indians' loss of sovereignty. Even in Britain's empire of "free trade" the concentration of sovereign power in London enabled the trans- 
formation of South Asia from a global textile powerhouse into an exporter of cotton to Manchester and opium to China (63). As textile manufacturing in England gave way to "iron, coal, and steel," the empire shifted from formal conquest to informal control. In Chapter 2, Kohli follows dependency scholars like Andre Gunder Frank in pointing to the emergence of a coalition of metropolitan and peripheral elites oriented around the exchange of Latin American raw materials for British industrial goods (75). Chapter 3 compares British imperialism in Africa and Asia to examine the links between finance, commerce, and imperialism in the late nineteenth century. Kohli rejects the Hobson-Lenin thesis on imperialism as the result of financialization but maintains the primacy of economic motivations for imperialist policy, particularly to secure markets for British industrial goods in the face of protectionist empires like France $(180,198)$. Drawing on scholars of rural commercialization like David Washbrook, Kohli contends that the alliance of British colonial states with indigenous landed elites delayed modernization, producing "backwardness" in the peripheral countryside (156-7).

In Part 2, Kohli constructs an original and interesting account of American imperialism as a form of informal empire functioning through multilateral coalitions of nation-states. Chapter 4 connects the American search for markets and influence, particularly in East Asia, to overproduction crises plaguing the industrial North after rapid industrialization following the Civil War (219). Kohli creatively finds the roots of American reliance on regime change and militarism in the early experience of empire-building in the Caribbean and the Philippines following the Spanish-American war (239). Further, he points to the Open Door policy in China as an early example of accomplishing imperialist goals through coalitions of nation-states, reshaping systems of interstate-relations in the process (244-5). In the following chapter on American responses to Third World nationalism in the 1950s and 60s, Kohli suggests that American imperialism, like the British Empire, depended on partnerships with landed elites with the ability to repress or co-opt their peasant masses to enshrine commodity export at the heart of peripheral economies (269). In Chapter 6, Kohli draws a line from American imperialism in the Philippines through the Vietnam War to the Gulf War, pointing to the common aims of opening and accessing key markets or strategic resources (329). Kohli innovatively compares the Washington Consensus and emergence of neoliberalism in the 1970s to the Victorian imperial strategy of using financial power to enforce deindustrialization through sovereign debt crises, decrying the World Bank and IMF's “international usury on a grand scale” $(347,350)$.

Kohli concludes the book with a resolution of "realist" and "Marxist" theories of imperialism through the conceptual category of "national economic prosperity" as the primary motivation of imperial policy (396). Kohli draws on Weber's suggestion that state and class operate as distinct and "autonomous realms of human activity" to argue that while economic motives predominate, modern imperialism cannot be reduced to the hand of "finance" (397). Thus, American im- 
perialism, aimed at toppling nationalist economic planning in the Third World, Soviet bloc, and at home, is not simply the natural outgrowth of "global capitalism" but intentional imperial policy constructed to preserve broadly defined national economic prosperity (403, 411-12). Kohli's review of British and American imperialism powerfully advances the concept of informal empire and demonstrates the significance of sovereignty in economic histories of imperialism.

His focus on the Hobson-Lenin thesis on imperialism, though, elides more recent developments flowing from other intellectual currents, like David Harvey's theory of the "spatial-fix" drawing on Rosa Luxemburg and Henri Lefebvre or Giovanni Arrighi's refinement of the world-systems approach. These approaches also draw attention to the importance of states and sovereign authority in generating the spatial and temporal relationships that constitute the "economy" and, therefore, economic growth. Overall, Kohli's important intervention into the role of imperialism in the history of capitalism points to a pressing need for more rigorous study of sovereignty in political economy. Imperialism and the Developing World is a creative and readable approach to the history of British and American imperialism and raises important questions, particularly for the Marxist tradition, about the nature of capitalist economic development.

Siddharth Sridhar University of Toronto 